\title{
Mineral Nutrition and Quality of Maiz (Zea Mays L.) as Affected by Household Waste Compost, Poultry Manure and Inorganic Fertilizers
}

\author{
${ }^{1}$ N. Hossain, ${ }^{2}$ M. G. Kibria, ${ }^{3}$ K. T. Osman \\ ${ }^{1,2,3}$ Department of Soil Science, University of Chittagong, Chittagong 4331,Bangladesh
}

\begin{abstract}
A field experiment was conducted to study the comparative effects of household waste compost, poultry manure and inorganic fertilizer on mineral nutrition and quality of maize (Zeamays L.). There were ten treatments, one control and nine fertilizer combinations. In three separate treatments, NPK, household compost and poultry manure were applied alone. In three treatments, NPK and compost were used in different proportions. In three other treatments, NPK and poultry manure were combined together. The results indicated that compost alone significantly increased $\mathrm{P}, \mathrm{K}, \mathrm{Ca}$ and $\mathrm{Mg}$ in shoot and root at $30 \mathrm{DAS}$ and at maturity as compared to control. Different treatments of compost in combination with inorganic fertilizers obtained higher $P$ concentrations in shoot and root at maturity compared with control treatment. Poultry manure alone significantly increased $N$ in shoot and root at 30 days after sowing (DAS); $P, K$, and $M g$ in shoot and root at 30 $D A S$ and at maturity as compared to control. By increasing the proportion of inorganic fertilizer combined with decreasing amount of poultry manure showed lower concentration of $P, K$ and $M g$ in shoot and root at both the stages as compared to poultry manure alone. Reducing sugar, non-reducing sugar and total soluble sugar contents in grains varied within the ranges of 4.00-5.33\%, 19.00-23.33\%, and 23.00-28.67\%, respectively. There was little difference in sugar contents among the treatments, although a relatively higher sugar was obtained with compost alone treatment.
\end{abstract}

Keywords: compost, nutrition, poultry manure, sugar.

\section{Introduction}

Maize is an important cereal crop that provides staple food to large number of human population in the world. It occupies third position in production next to wheat and rice in the world [1]. Now maize is one of the most important food grains in the world as well as in developing countries. Maize seeds contain about $80 \%$ starch, $10 \%$ proteins, $4.5 \%$ oil, $3.5 \%$ fiber and $2 \%$ minerals [2]. In the developed countries, about $90 \%$ of maize is used for animal feed and other for industrial by-products. Unlike in the developed countries, the same percentage (80 to 90\%) of maize is used as food in the world [3]. In Bangladesh, the cultivation of maize has been gaining popularity in recent years. It is now becoming an important cereal crop for its higher productivity and diversity of use. The agro-climatic condition of Bangladesh is favorable for its cultivation round the year. However, the average yield of maize in the country is considerably low. The national average yield is only 5.33 $\mathrm{tha}^{-1}$ [4], whereas the newly released varieties have the potential to produce more than $8.0 \mathrm{t} \mathrm{ha}^{-1}$.

Low soil organic matter content is the main cause of low productivity, and it is considered as one of the most serious threats to the sustainability of agriculture in Bangladesh. Most soils have less than $1.7 \%$ and some soils have less than $1.0 \%$ organic matter. Composting is considered as a traditional way of returning organic matter to the soil. It is believed that adding considerable quantities of compost to agricultural land will reverse the trend of soil organic matter reduction [5]. Bio waste and vegetable compost application can increase plant available $\mathrm{P}, \mathrm{K}[6,7]$ and $\mathrm{Mg}$ [8] levels of soils. Influence of compost on nutritional composition of shoots and grains of amaranths was reported by Oworu et al. [9]. The rate of nutrient uptake by amaranths was directly proportional to the quantity of the applied compost.

Poultry manure has been recognized as a valuable source of plant nutrients for crops. Madhavi and Reddy [10] opined that poultry manure is a potential source of plant nutrients like nitrogen (0.84 to $1.21 \%)$ phosphorus (0.91 to $1.07 \%)$ and potassium (1.35 to $2.35 \%)$. Poultry manure application registered over $53 \%$ increases of $\mathrm{N}$ level in the soil, from $0.09 \%$ to $0.14 \%$ and exchangeable cations increase with manure application [11]. In agriculture, the main reasons for applying poultry manure include the organic amendment of the soil and the provision of nutrients to crops [12]. An experiment conducted by Amanullah et al. [13] indicated that application of poultry manure registered higher uptake of NPK than control in cassava. Higher uptake of nutrients due to composted poultry manure either alone or with FYM might be due to increased availability of nutrients. Faiyard et al. [14] recorded an increase in N, P, K, Fe, $\mathrm{Mn}$ and $\mathrm{Cu}$ contents in faba beans due to application of poultry manure in comparison with FYM. Application of poultry manure +FYM was found to increase the availability in soil and subsequently the nutrient uptake in maize [15]. Protein content of mustard 
Mineral Nutrition and Quality of Maiz (Zea Mays L.) as Affected by Household Waste Compost, was increased by $12.59 \%$ over control with poultry manure application at $20 \mathrm{t} \mathrm{ha}^{-1}$ [16].

Balance fertilization using both organic and chemical fertilizers is important for maintenance of soil organic matter (OM) content and long term soil productivity in the tropics where OM content is low. A balanced and integrated use of organic and inorganic nutrient sources may help sustain crop production. The integrated use of organic nutrient sources with inorganic fertilizer was shown to increase the potential of organic fertilizer [17] and to improve the efficiency of inorganic fertilizer The availability of soil $\mathrm{N}$ is enhanced by addition of manures, presumably due to chelation of cations by organic acids and other decay products [18]. Application of organic manure in combination with chemical fertilizer has been reported to increase absorption of $\mathrm{N}, \mathrm{P}$, and $\mathrm{K}$ in sugarcane leaf tissue in the plant and ratoon crop, compared to chemical fertilizer alone [19]. Adekayode [20] found that wood ash, goat and poultry manures increased fat, protein and reduced carbohydrate in amaranths. While continuous use of fertilizers creates potential polluting effect in the environment [21] and chemical fertilizers consume a large amount of energy and money. However, an organic farming with or without chemical fertilizers seems to be possible solution for these situations[22, 23]. Keeping in view the above facts, the present study was therefore, designed to examine the effect of household waste compost, poultry manures and inorganic fertilizer alone and their different combination on the mineral nutrition and quality of maize.

\section{Materials And Methods}

\section{1. Field Experiment}

A field experiment was conducted to study the effects of organic and inorganic fertilizers on the mineral nutrition and quality of Maize (Zea mays L.) during Rabi season in 2010-2011 at the Crop Field of the Department of Soil Science, University of Chittagong. For the study, poultry manure was obtained from nearby poultry farms. Separately compost was prepared from household wastes collected from some of the University Halls. Thirty experimental plots $(2.2 \mathrm{~m} \times 2.2 \mathrm{~m})$ separated by $0.5 \mathrm{~m}$ margins were prepared in three adjacent blocks in the crop field. There were ten plots in each block for the ten treatment combinations comprising of poultry manure (PM), household waste compost and inorganic fertilizers- T1(Control), T2 (NPK alone @ 120 $\mathrm{kg} \mathrm{N} \mathrm{ha}{ }^{-1}, 60 \mathrm{~kg} \mathrm{Pha}^{-1}$ and $\left.80 \mathrm{~kg} \mathrm{~K} \mathrm{ha}^{-1}\right), \mathrm{T} 3$ (Compost alone @ $30 \mathrm{t} \mathrm{ha}^{-1}$ ), T4 (25\% NPK+75\% compost i.e. 30 $\mathrm{kg} \mathrm{N} \mathrm{ha}^{-1}, 15 \mathrm{~kg} \mathrm{Pha}^{-1}$ and $20 \mathrm{~kg} \mathrm{~K} \mathrm{ha}^{-1}+22.5 \mathrm{tha}^{-1}$ compost), T5 (50\% NPK $+50 \%$ compost i.e. $60 \mathrm{~kg} \mathrm{~N} \mathrm{ha}^{-1}, 30$ $\mathrm{kg} \mathrm{Pha}^{-1}$ and $40 \mathrm{~kg} \mathrm{~K} \mathrm{ha}^{-1}+15 \mathrm{tha}^{-1}$ compost), T6 (75\% NPK $+25 \%$ compost i.e. $90 \mathrm{~kg} \mathrm{~N} \mathrm{ha}^{-1}, 45 \mathrm{~kg} \mathrm{P}^{-1}$ and $60 \mathrm{~kg} \mathrm{~K} \mathrm{ha}^{-1}+7.5 \mathrm{t} \mathrm{ha}^{-1}$ compost), T7 (PM alone @ $\left.30 \mathrm{t} \mathrm{ha}^{-1}\right), \mathrm{T} 8\left(25 \% \mathrm{NPK}+75 \% \mathrm{PM}\right.$ i.e. $30 \mathrm{~kg} \mathrm{~N} \mathrm{ha}^{-1}, 15 \mathrm{~kg} \mathrm{P}$ $\mathrm{ha}^{-1}$ and $20 \mathrm{~kg} \mathrm{Kha}^{-1}+22.5 \mathrm{tha}^{-1} \mathrm{PM}$ ), T9 ( $50 \% \mathrm{NPK}+50 \%$ PM i.e.60 kg N ha ${ }^{-1}, 30 \mathrm{~kg} \mathrm{Pha}^{-1}$ and $40 \mathrm{~kg} \mathrm{~K} \mathrm{ha}^{-}$ $\left.{ }^{1}+15 \mathrm{tha}^{-1} \mathrm{PM}\right), \mathrm{T} 10\left(75 \% \mathrm{NPK}+25 \% \mathrm{PM}\right.$ i.e. $90 \mathrm{~kg} \mathrm{~N} \mathrm{ha}^{-1}, 45 \mathrm{~kg} \mathrm{Pha}^{-1}$ and $\left.60 \mathrm{~kg} \mathrm{~K} \mathrm{ha}^{-1}+7.5 \mathrm{tha}^{-1} \mathrm{PM}\right)$. The treatments were arranged according to a randomized complete block design. Nitrogen in the form of urea was applied in 3 splits. One-third of nitrogen fertilizer (i.e. urea) was applied as basal dose before sowing, the $2^{\text {nd }}$ dose was given after one month of sowing and the third installment was given at the flowering stage. Phosphorus and potassium fertilizers were also applied as basal. All of poultry manure and kitchen composts were applied basal at the final stage of soil preparation.

Maize variety Hybrid Corn seed 984 Gold (984 F-1 Hybrid Thailand) was used in the experiment. The seeds were sown in lines $75 \mathrm{~cm}$ apart with seed to seed distance of $25 \mathrm{~cm}$. In each point two seeds were sown. Seeds were sown at a depth of $2.5 \mathrm{~cm}$ below surface. Seedlings emerged after 6 to 7 days after sowing. One healthy seedling was retained in each point. There were finally eighteen plants in each plot. Irrigation was applied as and when necessary. The experimental plot was kept free of weeds by regular weeding. To control the pests and diseases, necessary plant protection measures including manual collection and destruction of Helicoverpa armigera larvae were done i.e. by using forceps, removal of infected plants leaf with knife also taken as and when required. The fruits were harvested when they were fully mature and turned to deep yellow colour after about four months.

\section{2. Determination of soil properties}

Soil texture was determined by hydrometer method [24], $\mathrm{pH}$ in a 1:2.5 soil/water suspension with glass electrode $\mathrm{pH}$ meter, organic carbon by wet-oxidation method [25] (Walkley and Black 1934), total nitrogen by micro-Kjeldahl digestion and distillation, available phosphorus by Bray and Kurtz-II method [26] and exchangeable potassium, calcium and magnesium by $1 \mathrm{~N} \mathrm{NH}_{4} \mathrm{OAC}$ saturation [27]. The experimental soil was sandy clay loam (68\% sand, $11 \%$ silt and $21 \%$ clay) with pH 4.18, organic matter content $1.20 \%$, CEC 6.71 cmol kg-1 , total nitrogen $0.07 \%$, available P (Bray \& Kurtz II P) $6 \mathrm{mg} \mathrm{kg}^{-1}$, exchangeable $\mathrm{K} 0.20 \mathrm{cmol} \mathrm{kg}^{-1}$, exchangeable Ca $1.94 \mathrm{cmol} \mathrm{kg}^{-1}$ and exchangeable $\mathrm{Mg} 1.05 \mathrm{cmol} \mathrm{kg}^{-1}$. Poultry manure used in the experiment contained pH 7.65, total nitrogen $0.28 \%$, available P (Bray \& Kurtz II P) $14.17 \mathrm{mg} \mathrm{kg}^{-1}$, exchangeable K 12.65 cmol kg${ }^{-1}$, exchangeable $\mathrm{Ca} 7.44 \mathrm{cmol} \mathrm{kg}^{-1}$ and exchangeable $\mathrm{Mg} \quad 0.44 \mathrm{cmol} \mathrm{kg}^{-1}$. Compost with $\mathrm{pH} 8.35$ contained total nitrogen $0.15 \%$, available P (Bray \& Kurtz II P) $4.77 \mathrm{mg} \mathrm{kg}^{-1}$, exchangeable K $34.65 \mathrm{cmol} \mathrm{kg}^{-1}$, exchangeable Ca $8.12 \mathrm{cmol} \mathrm{kg}^{-1}$ and exchangeable $\mathrm{Mg} \quad 0.38 \mathrm{cmol} \mathrm{kg}^{-1}$. 
Mineral Nutrition and Quality of Maiz (Zea Mays L.) as Affected by Household Waste Compost,

2. 3. Determination mineral nutrition and quality of maize

Oven dried $\left(65^{\circ} \mathrm{C}\right.$ to constant weight) and ground plant samples were digested with a mixture of $\mathrm{H}_{2} \mathrm{SO}_{4}, \mathrm{H}_{2} \mathrm{O}_{2}$ and lithium sulfate for the determination of $\mathrm{N}, \mathrm{P}, \mathrm{K}, \mathrm{Ca}$ and $\mathrm{Mg}$ in the plant tissues [28](Allen et al. 1986). The concentrations of $\mathrm{Ca}$ and $\mathrm{Mg}$ in the digest were measured by atomic absorption spectrophotometer (Varian nov AA). Micro-Kjeldahl method as described by Jackson [27] was used for the determination of nitrogen. Phosphorus was determined by vanadomolybdo phosphoric yellow colour method in nitric acid system according to Jackson [27]. Potassium was measured by flame photometer. Protein content of plant materials was obtained by multiplying the nitrogen value by 6.25 . Total soluble sugars, reducing sugar and non-reducing sugar were determined as described by Shahnawaz et al. [29].

\section{4. Statistical analysis}

The significance of differences between the means of the treatments was evaluated by one way analysis of variance followed by Duncan's Multiple Range Test at the significance level of 5\%. The statistical software Excel [30] and SPSS version 12 [31] were used for these analyses.

\section{RESULTS}

\section{1. Mineral nutrient concentration}

3. 1. 1. Nitrogen concentration

Nitrogen concentration varied significantly from 1.02 (T1) to $1.51 \%$ (T7-poultry manure alone) in shoot and 0.20 to $0.75 \%$ in root at 30 DAS in the same treatments (Table 1). In shoot at 30 DAS treatment T2 (NPK alone) and T3 (compost alone) had no significant difference with control treatment T1. Different combinations of NPK fertilizer and compost except T4 also show similar result compared with T1 treatment. At 30 DAS treatments $\mathrm{T} 2$ and $\mathrm{T} 3$ showed higher concentrations of $\mathrm{N}$ than treatment T1 in roots. Treatment T4, T5 and T6 are significantly different from control treatment but statistically similar with each other. By increasing the proportion of inorganic fertilizer combined with decreasing amount of poultry manure as in treatments T8, T9 and T10 concentration of $\mathrm{N}$ in maize shoot and root was reduced compared with the T7 treatment (poultry manure alone).

At maturity, nitrogen concentration in shoot ranged from 0.76 to $1.16 \%$. The treatments $\mathrm{T} 2, \mathrm{~T} 5, \mathrm{~T} 7$, $\mathrm{T} 8$ and $\mathrm{T} 9$ are statistically similar with each other but are significantly higher than treatment $\mathrm{T} 10$ that contained the lowest $\mathrm{N}$ concentration. The treatment $\mathrm{T} 1$ and $\mathrm{T} 4$ contained medium concentration of $\mathrm{N}$ compared with other treatments. The highest concentration of $\mathrm{N}$ in root was found in treatment $\mathrm{T} 6$ and the lowest was in treatment T1. Significantly higher values were found in treatment T2, T3 and T5 compared with the control treatment. Though different types of fertilizer combinations were used with poultry manure but there were no significant differences among treatments $\mathrm{T} 7, \mathrm{~T} 8, \mathrm{~T} 9$ and $\mathrm{T} 10$ compared with control treatment. Nitrogen concentration in grain at maturity ranged from 0.74 (T8) to $1.17 \%$ (T2). Treatment T1, T3, T5, T6, T7, T9 and $\mathrm{T} 10$ were statistically similar with the control. Treatments T2 andT4 increased the N concentration.

Table 1 Effects of household waste compost, poultry manure and inorganic fertilizers on nitrogen concentration (\%) in shoot, root and grain of maize

\begin{tabular}{clllll}
\hline \multirow{2}{*}{ Treatment } & \multicolumn{2}{c}{ 30 DAS } & \multicolumn{1}{c}{ At maturity } \\
\cline { 2 - 6 } & \multicolumn{1}{c}{ Shoot } & \multicolumn{1}{c}{ Root } & Shoot & \multicolumn{1}{c}{ Root } & Grain \\
\hline $\mathrm{T}_{1}$ & $1.02 \mathrm{c}$ & $0.20 \mathrm{e}$ & $0.87 \mathrm{bcd}$ & $0.28 \mathrm{~d}$ & $0.78 \mathrm{c}$ \\
$\mathrm{T}_{2}$ & $1.15 \mathrm{bc}$ & $0.31 \mathrm{~d}$ & $1.07 \mathrm{ab}$ & $0.48 \mathrm{~b}$ & $1.17 \mathrm{a}$ \\
$\mathrm{T}_{3}$ & $1.16 \mathrm{bc}$ & $0.38 \mathrm{c}$ & $0.8 \mathrm{~cd}$ & $0.38 \mathrm{c}$ & $0.79 \mathrm{c}$ \\
$\mathrm{T}_{4}$ & $1.35 \mathrm{ab}$ & $0.49 \mathrm{~b}$ & $1 \mathrm{abc}$ & $0.36 \mathrm{~cd}$ & $0.92 \mathrm{~b}$ \\
$\mathrm{~T}_{5}$ & $1.23 \mathrm{abc}$ & $0.45 \mathrm{~b}$ & $1.08 \mathrm{ab}$ & $0.55 \mathrm{ab}$ & $0.76 \mathrm{c}$ \\
$\mathrm{T}_{6}$ & $1.14 \mathrm{bc}$ & $0.48 \mathrm{~b}$ & $1.16 \mathrm{a}$ & $0.56 \mathrm{a}$ & $0.8 \mathrm{bc}$ \\
$\mathrm{T}_{7}$ & $1.51 \mathrm{a}$ & $0.75 \mathrm{a}$ & $1.07 \mathrm{ab}$ & $0.35 \mathrm{~cd}$ & $0.77 \mathrm{c}$ \\
$\mathrm{T}_{8}$ & $1.46 \mathrm{ab}$ & $0.49 \mathrm{~b}$ & $1.04 \mathrm{ab}$ & $0.30 \mathrm{~d}$ & $0.74 \mathrm{c}$ \\
$\mathrm{T}_{9}$ & $1.28 \mathrm{abc}$ & $0.35 \mathrm{~cd}$ & $1.1 \mathrm{ab}$ & $0.29 \mathrm{~d}$ & $0.81 \mathrm{bc}$ \\
$\mathrm{T}_{10}$ & $1.20 \mathrm{abc}$ & $0.30 \mathrm{~d}$ & $0.76 \mathrm{~d}$ & $0.31 \mathrm{~cd}$ & $0.83 \mathrm{bc}$ \\
\hline
\end{tabular}

Figures in the same column denoted by the same letter (s) did not differ significantly according to DMRT at $\mathrm{P}<0.05$.

\section{1. 2. Phosphorus concentration}

The concentration of P ranged significantly from 0.21 to $0.54 \%$ and 0.21 to $0.38 \%$ in shoot and root respectively at 30 DAS (Table 2). At maturity, $\mathrm{P}$ concentration in shoot, root and grain varied from 0.19 to 0.30 $\%, 0.18$ to $0.30 \%$ to 0.35 and $0.57 \%$ respectively. The highest concentration of $\mathrm{P}$ in shoots and roots at 30 DAS and in shoot, root and grain at maturity was found with T7 (Poultry manure alone) treatment. The lowest 
Mineral Nutrition and Quality of Maiz (Zea Mays L.) as Affected by Household Waste Compost, concentration of phosphorus in shoots and roots at both the stages and in grain at harvest was found with T1 treatment.

The concentrations of $\mathrm{P}$ in shoot at 30 DAS in treatment T2, T3, T8, T9 and T10 are significantly higher compared with control treatment T1. Different proportion of inorganic fertilizer combined with compost showed statistically similar P concentration in shoot at 30 DAS in treatment T4, T5 and T6. In root at 30 DAS, P concentration in treatment T2 and T10 did not show any significant difference compared with control (T1) treatment. Treatment T3, T4 and T6 are statistically similar and these treatments showed significant differences compared with control treatment T1. Phosphorus concentration in treatment T5 and T8 were found significantly higher than the control.

Different treatments of compost in combination with inorganic fertilizers obtained higher $\mathrm{P}$ concentrations in shoot and root at maturity compared with control treatment. Similar results were found with poultry manure and inorganic fertilizer combinations in shoot and grain at maturity. The treatments T2 and T10 did not differ significantly in P concentration in root at maturity from control T1. In grain at maturity $\mathrm{P}$ concentration in T4, T5 and T6 did not show any significant difference compared with control (T1) treatment. Application of increasing proportion of NPK with decreasing poultry manure in combination significantly decreased $\mathrm{P}$ concentration in root at maturity and showed relatively lower concentration of $\mathrm{P}$ in root at 30 DAS and in shoot and grain at maturity compared with poultry manure alone (T7).

Table 2 Effects of household waste compost, poultry manure and inorganic fertilizers on phosphorus (\%) concentration in shoot, root and grain of maize

\begin{tabular}{clllll}
\hline \multirow{2}{*}{ Treatment } & \multicolumn{2}{c}{ 30 DAS } & \multicolumn{3}{c}{ At maturity } \\
\cline { 2 - 6 } & \multicolumn{1}{c}{ Shoot } & \multicolumn{1}{c}{ Root } & Shoot & \multicolumn{1}{c}{ Root } & Grain \\
\hline $\mathrm{T}_{1}$ & $0.21 \mathrm{f}$ & $0.21 \mathrm{e}$ & $0.19 \mathrm{~d}$ & $0.18 \mathrm{~d}$ & $0.35 \mathrm{e}$ \\
$\mathrm{T}_{2}$ & $0.27 \mathrm{de}$ & $0.23 \mathrm{e}$ & $0.20 \mathrm{~d}$ & $0.20 \mathrm{~d}$ & $0.49 \mathrm{abc}$ \\
$\mathrm{T}_{3}$ & $0.30 \mathrm{~cd}$ & $0.28 \mathrm{~d}$ & $0.23 \mathrm{c}$ & $0.23 \mathrm{c}$ & $0.47 \mathrm{bcd}$ \\
$\mathrm{T}_{4}$ & $0.24 \mathrm{ef}$ & $0.31 \mathrm{~cd}$ & $0.24 \mathrm{c}$ & $0.25 \mathrm{bc}$ & $0.43 \mathrm{cde}$ \\
$\mathrm{T}_{5}$ & $0.22 \mathrm{ef}$ & $0.36 \mathrm{ab}$ & $0.25 \mathrm{c}$ & $0.27 \mathrm{~b}$ & $0.42 \mathrm{cde}$ \\
$\mathrm{T}_{6}$ & $0.22 \mathrm{ef}$ & $0.31 \mathrm{~cd}$ & $0.23 \mathrm{c}$ & $0.25 \mathrm{bc}$ & $0.40 \mathrm{de}$ \\
$\mathrm{T}_{7}$ & $0.54 \mathrm{a}$ & $0.38 \mathrm{a}$ & $0.30 \mathrm{a}$ & $0.30 \mathrm{a}$ & $0.57 \mathrm{a}$ \\
$\mathrm{T}_{8}$ & $0.38 \mathrm{~b}$ & $0.36 \mathrm{ab}$ & $0.29 \mathrm{a}$ & $0.27 \mathrm{~b}$ & $0.56 \mathrm{a}$ \\
$\mathrm{T}_{9}$ & $0.40 \mathrm{~b}$ & $0.33 \mathrm{bc}$ & $0.28 \mathrm{ab}$ & $0.25 \mathrm{bc}$ & $0.52 \mathrm{ab}$ \\
$\mathrm{T}_{10}$ & $0.33 \mathrm{c}$ & $0.23 \mathrm{e}$ & $0.26 \mathrm{bc}$ & $0.18 \mathrm{~d}$ & $0.46 \mathrm{bcd}$ \\
\hline
\end{tabular}

Figures in the same column denoted by the same letter (s) did not differ significantly according to DMRT at $\mathrm{P}<0.05$

\section{1. 3. Potassium concentration}

At 30 DAS potassium concentration in shoot ranged from 1.29 (T5) to $2.38 \%$ (T7) (Table 3). The treatments T5 and T10 gave similar K concentration to the control. The treatments T2, T3, T4, T6, T8, and T9 were statistically similar to treatment T7 where poultry manure alone were added. Thus, most fertilizer combinations increased $\mathrm{K}$ concentration in shoot to the same extent. Increasing the proportion of inorganic fertilizer combined with decreasing amount of poultry manure represents the lower concentration of $\mathrm{K}$ in comparison with the treatment T7 in maize shoot. Potassium concentration in root at 30 DAS varied from 1.94 (Control) to $2.54 \%$ (poultry manure alone). NPK alone (T2) and compost alone (T3) had no significant differences in $\mathrm{K}$ concentration compared with the control. Concentration of $\mathrm{K}$ in root regularly decreased with increasing proportion of NPK fertilizer combined with decreasing proportion of poultry manure in treatment T8, $\mathrm{T} 9$ and T10. Increasing proportion of NPK with decreasing proportion of compost had negative affects on K concentration in T4, T5 and T6 compared with T7 treatment.

Potassium concentration in shoot at maturity ranged from 0.66 (Control) to $2.17 \%$ (Poultry manure alone) and in root from 1.64 to 2.35 in the same treatments. Application of NPK fertilizer alone (T2) significantly increased the concentration of $\mathrm{K}$ in shoot compared with control treatment. In treatment $\mathrm{T} 2$ similar amount of $\mathrm{K}$ to control was present in root. Though different combinations of inorganic fertilizers and compost were given in treatments T4, T5, and T6 but there were no significant differences of $\mathrm{K}$ in shoot and root as compared with $\mathrm{T} 3$ where compost alone was applied, but all of these treatments significantly differed from control treatment. Different combination of NPK fertilizers with poultry manure showed significantly different $\mathrm{K}$ with control in shoot and root but they were similar with treatment $\mathrm{T} 7$ where full poultry manure was applied. 
Mineral Nutrition and Quality of Maiz (Zea Mays L.) as Affected by Household Waste Compost,

Table 3 Effects of household waste compost, poultry manure and inorganic fertilizers on potassium concentration (\%) in shoot, root and grain of maize

\begin{tabular}{clllll}
\hline \multirow{2}{*}{ Treatment } & \multicolumn{2}{c}{ 30 DAS } & \multicolumn{3}{c}{ At maturity } \\
\cline { 2 - 6 } & Shoot & Root & Shoot & Root & Grain \\
\hline $\mathrm{T}_{1}$ & $1.45 \mathrm{~b}$ & $1.94 \mathrm{c}$ & $0.66 \mathrm{~b}$ & $1.64 \mathrm{~b}$ & $0.42 \mathrm{e}$ \\
$\mathrm{T}_{2}$ & $2.20 \mathrm{a}$ & $2.09 \mathrm{bc}$ & $1.90 \mathrm{a}$ & $1.96 \mathrm{ab}$ & $0.55 \mathrm{~d}$ \\
$\mathrm{~T}_{3}$ & $2.32 \mathrm{a}$ & $2.26 \mathrm{abc}$ & $2.09 \mathrm{a}$ & $2.19 \mathrm{a}$ & $0.64 \mathrm{~cd}$ \\
$\mathrm{~T}_{4}$ & $2.26 \mathrm{a}$ & $2.38 \mathrm{ab}$ & $2.03 \mathrm{a}$ & $2.18 \mathrm{a}$ & $0.78 \mathrm{~b}$ \\
$\mathrm{~T}_{5}$ & $1.29 \mathrm{~b}$ & $2.34 \mathrm{ab}$ & $2.05 \mathrm{a}$ & $2.23 \mathrm{a}$ & $0.72 \mathrm{bc}$ \\
$\mathrm{T}_{6}$ & $2.04 \mathrm{a}$ & $2.44 \mathrm{ab}$ & $2.06 \mathrm{a}$ & $2.19 \mathrm{a}$ & $0.69 \mathrm{bc}$ \\
$\mathrm{T}_{7}$ & $2.38 \mathrm{a}$ & $2.54 \mathrm{a}$ & $2.17 \mathrm{a}$ & $2.35 \mathrm{a}$ & $0.97 \mathrm{a}$ \\
$\mathrm{T}_{8}$ & $2.34 \mathrm{a}$ & $2.48 \mathrm{a}$ & $2.14 \mathrm{a}$ & $2.21 \mathrm{a}$ & $0.94 \mathrm{a}$ \\
$\mathrm{T}_{9}$ & $2.07 \mathrm{a}$ & $2.46 \mathrm{ab}$ & $2.12 \mathrm{a}$ & $2.16 \mathrm{a}$ & $0.92 \mathrm{a}$ \\
$\mathrm{T}_{10}$ & $1.83 \mathrm{ab}$ & $2.39 \mathrm{ab}$ & $1.85 \mathrm{a}$ & $2.04 \mathrm{a}$ & $0.65 \mathrm{~cd}$ \\
\hline
\end{tabular}

Figures in the same column denoted by the same letter (s) did not differ significantly according to DMRT at $\mathrm{P}<0.05$.

In grain $\mathrm{K}$ concentration varied from 0.42 (Control) to $0.97 \%$ (Poultry manure alone) at maturity. Application of NPK fertilizer alone, compost alone and $75 \% \mathrm{NPK}+25 \%$ poultry manure in treatment T2, T3 and in T10 increased concentration of K significantly compared with control. Amount of K decreased gradually in treatment $\mathrm{T} 4, \mathrm{~T} 5$ and $\mathrm{T} 6$ where increasing proportion of synthetic fertilizer combined with decreasing proportion of compost were arranged compared with treatment T7. Mostly higher concentrations of $\mathrm{K}$ were observed in treatments $\mathrm{T} 8$ and $\mathrm{T} 9$ compared with the highest level of $\mathrm{K}$ that was found in $\mathrm{T} 7$ treatment.

\section{1. 4. Calcium concentration}

Calcium concentration in shoot of maize varied from 0.20 (control) to $0.32 \%$ (T4 and T5) at 30 DAS (Table 4). Treatments $\mathrm{T} 2$ (compost alone), T8, T9 and T10 showed similar concentration of $\mathrm{Ca}$ and no significant difference was found compared with control. Compost alone (T3) and poultry manure alone (T7) contained higher amounts of $\mathrm{Ca}$ than that of control treatment. Decreasing trend of $\mathrm{Ca}$ concentration was found in treatment T8, T9 and T10 compared with treatment T7.

The highest concentration of $\mathrm{Ca}$ at $30 \mathrm{DAS}$ in root was found to be $0.27 \%$ in the treatment $\mathrm{T} 4$ whereas, the lowest was found in the control $(0.16 \%$; T1) treatment. The second highest concentration was found in treatments T3 $(0.24 \%)$, T5 $(0.25 \%)$ and T8 $(0.25 \%)$ which significantly differed from the control. Same amount of Ca concentration had been found in T6 $(0.22 \%)$ and T7 $(0.22 \%)$ treatments. Treatments T9 $(0.19 \%)$ and T10 $(0.20 \%)$ produced significant difference from control though these treatments were statistically similar with each other.

Table 4 Effects of household waste compost, poultry manure and inorganic fertilizers on calcium concentration $(\%)$ in shoot, root and grain of maize

\begin{tabular}{clllll}
\hline \multirow{2}{*}{ Treatment } & \multicolumn{2}{c}{ 30 DAS } & \multicolumn{3}{c}{ At maturity } \\
\cline { 2 - 5 } & \multicolumn{1}{c}{ Shoot } & \multicolumn{1}{c}{ Root } & \multicolumn{1}{c}{ Shoot } & \multicolumn{1}{c}{ Root } & Grain \\
\hline $\mathrm{T}_{1}$ & $0.20 \mathrm{e}$ & $0.16 \mathrm{e}$ & $0.24 \mathrm{c}$ & $0.18 \mathrm{f}$ & $0.02 \mathrm{c}$ \\
$\mathrm{T}_{2}$ & $0.21 \mathrm{de}$ & $0.18 \mathrm{de}$ & $0.26 \mathrm{c}$ & $0.20 \mathrm{ef}$ & $0.04 \mathrm{ab}$ \\
$\mathrm{T}_{3}$ & $0.30 \mathrm{ab}$ & $0.24 \mathrm{ab}$ & $0.36 \mathrm{ab}$ & $0.28 \mathrm{c}$ & $0.04 \mathrm{ab}$ \\
$\mathrm{T}_{4}$ & $0.32 \mathrm{a}$ & $0.27 \mathrm{a}$ & $0.39 \mathrm{a}$ & $0.34 \mathrm{ab}$ & $0.05 \mathrm{a}$ \\
$\mathrm{T}_{5}$ & $0.32 \mathrm{a}$ & $0.25 \mathrm{ab}$ & $0.36 \mathrm{ab}$ & $0.36 \mathrm{a}$ & $0.04 \mathrm{ab}$ \\
$\mathrm{T}_{6}$ & $0.28 \mathrm{abc}$ & $0.22 \mathrm{bc}$ & $0.35 \mathrm{~b}$ & $0.25 \mathrm{~cd}$ & $0.03 \mathrm{bc}$ \\
$\mathrm{T}_{7}$ & $0.26 \mathrm{bcd}$ & $0.22 \mathrm{bc}$ & $0.27 \mathrm{c}$ & $0.32 \mathrm{~b}$ & $0.04 \mathrm{ab}$ \\
$\mathrm{T}_{8}$ & $0.24 \mathrm{cde}$ & $0.25 \mathrm{ab}$ & $0.27 \mathrm{c}$ & $0.34 \mathrm{ab}$ & $0.04 \mathrm{ab}$ \\
$\mathrm{T}_{9}$ & $0.22 \mathrm{de}$ & $0.19 \mathrm{~cd}$ & $0.25 \mathrm{c}$ & $0.22 \mathrm{de}$ & $0.04 \mathrm{ab}$ \\
$\mathrm{T}_{10}$ & $0.21 \mathrm{de}$ & $0.20 \mathrm{~cd}$ & $0.26 \mathrm{c}$ & $0.23 \mathrm{de}$ & $0.03 \mathrm{bc}$ \\
\hline
\end{tabular}

Figures in the same column denoted by the same letter (s) did not differ significantly according to DMRT at $\mathrm{P}<0.05$.

At maturity Ca concentration ranged from 0.24 (T1; control) to $0.39 \%$ (T4) in shoot. Treatments $\mathrm{T} 2$, T7, T8, T9 and T10 represented similar values and were not significant compared with control treatment. Treatments T3 and T5 showed the same concentration of Ca but significantly different from control treatment. Treatment T6 increased the Ca concentration in shoot compared with control treatment T1.

At maturity, root of maize contained $\mathrm{Ca}$ concentration from 0.18 (Control; T1) to $0.36 \%$ (T5). Although $\mathrm{Ca}$ value was increased in treatment $\mathrm{T} 2$, it was not significantly different from treatment $\mathrm{T} 1$. Comparing the values with control treatment positive significant differences were found in treatments T3, T6, 
Mineral Nutrition and Quality of Maiz (Zea Mays L.) as Affected by Household Waste Compost,

T7, T9 and T10 . Grain Ca concentration varied from 0.02 (control) to $0.05 \%$ (25\% NPK+ 75\% Compost). Values for the treatments $\mathrm{T} 2, \mathrm{~T} 3, \mathrm{~T} 5, \mathrm{~T} 7, \mathrm{~T} 8$, and $\mathrm{T} 9$ respectively were similar but the treatments were significantly different from the control. The treatment T6 and T10 performed similarly to treatment T1.

\section{1. 5. Magnesium concentration}

At 30 DAS shoot $\mathrm{Mg}$ concentration ranged from 0.13 (control) to $0.19 \%$ (Poultry manure alone) (Table 5). Although increasing the proportion of inorganic fertilizer combined with decreasing proportion of poultry manure in treatments $\mathrm{T} 8, \mathrm{~T} 9$ and $\mathrm{T} 10$ had statistically similar values, but these treatments were significantly different from treatment T1. Application of NPK fertilizer alone (T2) and fertilizer combinations with compost in treatments T4, T5, T6 showed no significant difference compared with control treatment T1. Magnesium concentration in root at 30 DAS ranged from 0.10 (Control) to $0.14 \%$ (Poultry manure). But different amendments of organic and inorganic fertilizers showed no significant difference among all treatments. At 30 DAS there had no significant effect of fertilizers on Mg concentration in maize.

Table 5 Effects of household waste compost, poultry manure and inorganic fertilizers on magnesium concentration (\%) in shoot, root and grain of maize

\begin{tabular}{clllll}
\hline \multirow{2}{*}{ Treatment } & \multicolumn{2}{c}{ 30 DAS } & \multicolumn{3}{l}{ At maturity } \\
\cline { 2 - 6 } & Shoot & Root & Shoot & Root & Grain \\
\hline $\mathrm{T}_{1}$ & $0.13 \mathrm{~d}$ & $0.10 \mathrm{a}$ & $0.14 \mathrm{~d}$ & $0.12 \mathrm{e}$ & $0.04 \mathrm{c}$ \\
$\mathrm{T}_{2}$ & $0.15 \mathrm{~cd}$ & $0.12 \mathrm{a}$ & $0.21 \mathrm{~b}$ & $0.19 \mathrm{~b}$ & $0.05 \mathrm{~b}$ \\
$\mathrm{~T}_{3}$ & $0.16 \mathrm{bc}$ & $0.12 \mathrm{a}$ & $0.19 \mathrm{bc}$ & $0.17 \mathrm{bc}$ & $0.05 \mathrm{~b}$ \\
$\mathrm{~T}_{4}$ & $0.15 \mathrm{~cd}$ & $0.13 \mathrm{a}$ & $0.20 \mathrm{bc}$ & $0.15 \mathrm{~cd}$ & $0.05 \mathrm{~b}$ \\
$\mathrm{~T}_{5}$ & $0.14 \mathrm{~cd}$ & $0.12 \mathrm{a}$ & $0.18 \mathrm{c}$ & $0.13 \mathrm{de}$ & $0.05 \mathrm{~b}$ \\
$\mathrm{~T}_{6}$ & $0.13 \mathrm{~d}$ & $0.11 \mathrm{a}$ & $0.15 \mathrm{~d}$ & $0.14 \mathrm{de}$ & $0.05 \mathrm{~b}$ \\
$\mathrm{~T}_{7}$ & $0.19 \mathrm{a}$ & $0.14 \mathrm{a}$ & $0.24 \mathrm{a}$ & $0.22 \mathrm{a}$ & $0.06 \mathrm{a}$ \\
$\mathrm{T}_{8}$ & $0.18 \mathrm{a}$ & $0.13 \mathrm{a}$ & $0.21 \mathrm{~b}$ & $0.19 \mathrm{~b}$ & $0.05 \mathrm{~b}$ \\
$\mathrm{~T}_{9}$ & $0.17 \mathrm{ab}$ & $0.12 \mathrm{a}$ & $0.20 \mathrm{bc}$ & $0.17 \mathrm{bc}$ & $0.05 \mathrm{~b}$ \\
$\mathrm{~T}_{10}$ & $0.16 \mathrm{bc}$ & $0.12 \mathrm{a}$ & $0.20 \mathrm{bc}$ & $0.17 \mathrm{bc}$ & $0.05 \mathrm{~b}$ \\
\hline
\end{tabular}

Figures in the same column denoted by the same letter (s) did not differ significantly according to DMRT at P $<0.05$.

In shoot of maize, magnesium concentration at maturity varied from 0.14 (T1; Control) to $0.24 \%$ (T7; Poultry manure alone). The values of $\mathrm{Mg}$ concentration in treatment $\mathrm{T} 2, \mathrm{~T} 3, \mathrm{~T} 4$ and $\mathrm{T} 5$ varied significantly with control treatment T1. Magnesium value in treatment T6 was statistically similar with the control treatment T1. The treatment T8, T9 and T10 varied from control treatment T1.

The highest magnesium concentration in root was found in Treatment $\mathrm{T} 7$ where poultry manure alone was applied, and the lowest value was found in control treatment $\mathrm{T} 1$. In different treatments $\mathrm{T} 2, \mathrm{~T} 3$ and $\mathrm{T} 4 \mathrm{Mg}$ concentration significantly varied from treatment T1. Treatment T5 and T6 were statistically similar with control. By the different combinations of inorganic fertilizers with poultry manure data showed that treatments $\mathrm{T} 8, \mathrm{~T} 9$ and $\mathrm{T} 10$ were significantly different from the control.

Magnesium concentration in grain at maturity ranged from 0.04 (control) to $0.06 \%$ (Poultry manure alone. Although different amendments of organic, inorganic fertilizers showed similar value in T2, T3, T4, T5, T6, T8, T9 and T10 treatments but these treatments were significantly different from control treatment.

\section{2. Sugar and protein content in maize grain}

3. 2. 1. Sugar content

Results on sugar and protein contents of maize grain grown under different fertilizer treatments are presented in Table 6. Reducing sugar content ranged from 4.00 (control) to $5.33 \%$ (25\% NPK+ $75 \%$ poultry manure), respectively. Although reducing sugar in grains of maize in plots receiving fertilizers had higher values of reducing sugars, there was no significant difference among fertilizer treatments and from control.

Non-reducing sugar content varied from 19.00 (control) to $23.33 \%$ (25\% NPK+ 75\% compost). There was also no significant variation in non-reducing sugar content among the treatments.

Total soluble sugar content in maize grain varied from 23.00 (control) to $28.67 \%$ (25\% NPK+ $75 \%$ compost). In treatment T5 (50\% NPK+ 50\% compost) and T6 (75\% NPK + 25\% compost) total soluble sugar content were the same (24.33\%) in amount. Although treatments T2 $(26.33 \%)$, T3 (27.67\%), T7 (26.00\%), T8 $(28.00 \%)$, T9 $(27.33 \%)$ and T10 $(24.00 \%)$ gave different values of total soluble sugar but these values were not significantly different from the control. 
Mineral Nutrition and Quality of Maiz (Zea Mays L.) as Affected by Household Waste Compost,

Table 6 Effects of household waste compost, poultry manure and inorganic fertilizers on the sugar and protein contents of maize

\begin{tabular}{ccccc}
\hline Treatment & $\begin{array}{c}\text { Reducing } \\
\text { sugar }(\boldsymbol{\%})\end{array}$ & $\begin{array}{c}\text { Non-reducing } \\
\text { sugar }(\boldsymbol{\%})\end{array}$ & $\begin{array}{c}\text { Total soluble } \\
\text { sugar }(\boldsymbol{\%})\end{array}$ & $\begin{array}{c}\text { Crude protein } \\
(\boldsymbol{\%})\end{array}$ \\
\hline T1 & $4.00 \mathrm{a}$ & $19.00 \mathrm{a}$ & $23.00 \mathrm{~b}$ & $4.85 \mathrm{~d}$ \\
T2 & $4.67 \mathrm{a}$ & $21.67 \mathrm{a}$ & $26.33 \mathrm{ab}$ & $7.33 \mathrm{bc}$ \\
T3 & $5.00 \mathrm{a}$ & $22.67 \mathrm{a}$ & $27.67 \mathrm{ab}$ & $4.94 \mathrm{~d}$ \\
T4 & $5.33 \mathrm{a}$ & $23.33 \mathrm{a}$ & $28.67 \mathrm{a}$ & $10.08 \mathrm{a}$ \\
T5 & $4.67 \mathrm{a}$ & $19.67 \mathrm{a}$ & $24.33 \mathrm{ab}$ & $5.77 \mathrm{~cd}$ \\
T6 & $4.67 \mathrm{a}$ & $19.67 \mathrm{a}$ & $24.33 \mathrm{ab}$ & $4.77 \mathrm{~d}$ \\
T7 & $4.33 \mathrm{a}$ & $21.67 \mathrm{a}$ & $26.00 \mathrm{ab}$ & $5.02 \mathrm{~d}$ \\
T8 & $5.33 \mathrm{a}$ & $22.67 \mathrm{a}$ & $28.00 \mathrm{a}$ & $8.98 \mathrm{ab}$ \\
T9 & $4.67 \mathrm{a}$ & $22.67 \mathrm{a}$ & $27.33 \mathrm{ab}$ & $7.56 \mathrm{bc}$ \\
T10 & $4.33 \mathrm{a}$ & $19.67 \mathrm{a}$ & $24.00 \mathrm{ab}$ & $5.19 \mathrm{~d}$
\end{tabular}

Figures in the same column denoted by the same letter (s) did not differ significantly according to DMRT at $\mathrm{P}<0.05$.

\section{2. 2. Crude protein content}

The highest value of crude protein was found in treatment T4 $(10.08 \%)$ where $25 \% \mathrm{NPK}+75 \%$ compost were applied and the lowest value was found in treatment T6 $(4.77 \%)$ which was treated with $75 \%$ NPK $+25 \%$ compost. The second highest value $(8.98 \%)$ was obtained by the addition of $25 \%$ NPK+ $75 \%$ poultry manure (T8). Similar protein contents were observed in treatments T1 (4.85 \%), T3 (4.94 \%), T7 (5.02 $5)$ and T10 (5.19\%) and these were not statistically different from the lowest value of treatment T6. Application of NPK fertilizer alone (T2), 50\% NPK+ 50\% compost (T5 ) and 50\% NPK+ 50\% poultry manure (T9) gave significantly different protein content in maize grain from treatment T4 and T6.

\section{Discussion}

\section{1. Mineral nutrient concentration}

Status of nutrition of maize was evaluated from the concentrations of some major nutrient elements in maize shoot, root and grains. The elements were nitrogen, phosphorus, potassium, calcium and magnesium. The concentrations of the corresponding elements in young maize shoot varied from 1.02-1.51\%, 0.21-0.54\%, 1.29 $2.38 \%, 0.20-0.32 \%$ and $0.13-0.19 \%$. The seedlings were vigorously growing then and these concentrations should well reflect their state of nutrition. Comparable values of these nutrients were earlier reported in maize shoot by many investigators. For example, Muhammad and Khattak [32] observed 0.64 to $0.80 \% \mathrm{~N}, 0.11$ to $0.18 \% \mathrm{P}$ and 1.62 to $2.35 \% \mathrm{~K}$ in shoot of maize plants grown with press mud in saline soils. Much higher concentrations of $\mathrm{K}(2.0$ to $4.7 \%)$ and $\mathrm{P}(0.47$ to $0.82 \%)$ in shoot of maize were reported by Aziz et al. [33]. They used farmyard manure, poultry manure and press mud as amendments. Higher values were obtained with press mud and the lower values with farmyard manures. Poultry manure gave intermediate values. They further mentioned that potassium concentration in shoots was significantly more in plants grown with either source of organic manure than in plants grown without organic manure addition. Maximum increase in shoot $\mathrm{K}$ concentration was observed when press mud was added at the rate of 10 tons ha ${ }^{-1}$ followed by poultry manure and farm yard manure. The increase in $\mathrm{K}$ concentration, because of added organic matter may be attributed to $\mathrm{K}$ concentration of organic matter and improved root growth. Better root growth is responsible increased nutrient uptake in plants [34]. The uptake of nutrients and their distribution to different parts of the maize plants have been found to vary primarily with the fertility of the native soil, application of chemical fertilizers, the growth stage of the plant and the environmental conditions [35]. Several workers found that fertilization with nitrogen increased the concentration of nitrogen and phosphorus in plant tissue [36] as well as increasing potassium concentration in the plant [37].

Bruns et al. [38] conducted an experiment on the effects of variable fertility treatments on the yield and nutrition of maize. They observed that increased $\mathrm{N}$ fertility increased $\mathrm{N}$ in mature grains. This increase combined with the increase in grain yield per plant due to increased $\mathrm{N}$ fertility resulted in significantly more total $\mathrm{N}$ per plant in the grain at $\mathrm{N}$ fertility levels above $179 \mathrm{~kg} \mathrm{~N}^{-1}$. Both $\mathrm{N}$ and $\mathrm{K}$ fertility treatments had no effect on $\mathrm{P}$ content except in stover, where a significant increase in $\mathrm{P}$ content was observed with increasing levels of $\mathrm{K}$ fertility. Kurtz and Smith [39] reported that increases in $\mathrm{N}$ fertility generally increased protein content in maize grain, which will be the primary form of $\mathrm{N}$ found in the tissue. These data showed that maize crops increased their overall uptake of $\mathrm{K}$ when additional $\mathrm{K}$ fertilizer was applied, but that rates above $45 \mathrm{~kg} \mathrm{~K} \mathrm{ha}{ }^{-1}$ may not be economically beneficial to the maize. 
Mineral Nutrition and Quality of Maiz (Zea Mays L.) as Affected by Household Waste Compost,

\section{2. Sugar and protein contents in maize grain}

Reducing sugar, non-reducing sugar and total soluble sugar contents in grains varied within the ranges of $4.00-5.33 \%, 19.00-23.33 \%$, and $23.00-28.67 \%$, respectively. There was little difference in sugar contents among the treatments, although a relatively higher sugar was obtained with full compost treatment. Crude protein in grains varied from 4.77 to $10.08 \%$. The control and T6 (75\% NPK $+25 \%$ Compost) had given the minimum value and T4 (compost alone) gave the highest value. Arun Kumar et al. [40] found the grains to have a reducing sugar level of 2.3-3.2\%. Considerably higher reducing sugar content was found in the present study. This may be due to difference in the variety. Tabeke et al. [41] observed that although growth of maize was accelerated with compost there was little difference in sugar content whether the $\mathrm{N}$ source was compost or chemical fertilizer. Arun Kumar et al.[40] observed a variation of non-reducing sugar content from $17.01 \%$ in to $24.38 \%$. They used different proportion of recommended doses of N and P (RDN and RDP, respectively). The treatments in which only 50\% of RDN, irrespective of $\mathrm{P}$ and $\mathrm{K}$ levels was applied accounted for significantly lower non-reducing sugar content in grain. Decreasing P level resulted in lower content of sugar indicating importance of P nutrition in enhancing sugar content. Thus, application of 100\% RDP along with either $75 \%$ of RDN or $100 \%$ RDN of grain maize increased reducing sugar, non-reducing sugar and total sugar. The non-reducing sugar and total sugar content of maize grains in the present study corroborate well with ranges reported by Arun Kumar et al. [40].

Almodares et al. [42] obtained $8 \%$ protein in maize grains grown with $200 \mathrm{~kg} \mathrm{ha}^{-1}$ urea treatment. Naserirad et al. [43] observed 9.44 to $11.05 \%$ protein in grains of different varieties of maize. These values are in well agreement with the values of the present study. In the study of Arun Kumar et al.[40], the per cent protein content varied widely among the treatments from the lowest content of $8.80 \%$ to the highest of $10.32 \%$. The treatments which received $100 \%$ of RDN irrespective of $\mathrm{P}$ and $\mathrm{K}$ levels recorded higher protein content. This might be due to increased availability of nitrogen and its uptake and storage in grain. Nitrogen being the essential constituent that makes up to $16 \%$ by weight of protein is found to influence the protein content, if it is available in abundance [44]. The importance of nitrogen nutrition in protein content of maize was studied by many investigators. For example, Thomas et al. [45] reported that when $\mathrm{N}$ was sufficient protein content was $55 \%$, but when $\mathrm{N}$ was deficient the value changed to $25 \%$. Protein content did not increase significantly with the addition of $40 \mathrm{~kg} \mathrm{~N} \mathrm{ha}^{-1}$, but increased with higher levels of $\mathrm{N}$ to $160 \mathrm{~kg} \mathrm{ha}^{-1}$ [46].

\section{Conclusion}

Poultry manure provided the highest nitrogen and other nutrients which have contributed to the improvement in quality of maize. However, the compost prepared from the household wastes also gave satisfactory mineral nutrition.

\section{References}

[1] M.E.M.H. Amin, Effect of organic fertilizer and urea on growth, yield and quality of fodder maize (Zea mays L.), International Journal Current Research, 8, 2010, 35-41

[2] S.R. Reddy, Agronomy of field crop (India, Kalyani Publishers, 2006)

[3] R.K. Rajoo, Maize the golden grain of Himachal Pradesh (India, Kalyani Publishers, 1998)

[4] BBS (Bangladesh Bureau of Statistics), Statistical Year Book of Bangladesh, Statistics Division, Ministry of Planning: Govt. of the Peoples Republic of Bangladesh, Dhaka, 2005.

[5] EA (Environment Agency), Waste technology data centre. Available at: www.environment-agency.gov.uk/wtd/679004/679026/, (2007), Accessed: 2011.

[6] W. Hartl, B Putz and E.Erhart, Influence of rates and timing of biowaste compost application on rye yield and soil nitrate level, European Journal of Biology, 39, 2003, 129-139.

[7] F. Martínez, R.C. Cuevas and I.Walter, Biowaste effects on soil and native plants in a semiarid ecosystem, Journal of Environmental Quality, 32, 2003, 472-479.

[8] J. Weber, A. Karczewska, J. Drozd, S. Licznar, E. Jamroz and A. Kocowicz, Agricultural and ecological aspects of a sandy soil as affected by the application of municipal solid waste composts, Soil Biology and Biochemistry. 39 (6), 2007, 1294-1302

[9] O. O. Oworu, O. A. Dada and O. E. Majekodunmi, Influence of compost on growth, nutrient uptake and dry matter partitioning of grain amaranths( Amaranthus hypochondriacus L.), Libyan Agricultural Research Centre Journal International, 1(6), 2010, 375383 .

[10] B. L. Madhavi and S. M.Reddy, Effect of poultry manure on soil fertility and maize yield, Proc. National Seminar on Development in Soil Science (extended summaries), Diamond Jubilee of Indian Society of Soil Science, 1994, 285-287

[11] S. Boateng, A.J. Zickermann and M. Kornaharens, Effect of poultry manure on growth and yield of maize, West African Journal of Applied Ecology, 9, 2006, 1-11.

[12] J.G. Warren, S.B. Phillips, G.L. Mullins, D. Keahey and C.J. Penn, Environmental and production consequences of using alumamended poultry litter as a nutrient source for corn, Journal of Environmental Quality, 35, 2006, 172-182.

[13] M. M Amanullah, E. Somasundaram, K. Vaiyapuri and K. Sathyamoorthi, Poultry manure to crops: A Review, Agriculture Review, $28,2007,216-222$.

[14] M. N. Faiyard, M. M. Shehata and S. W. Barsoom, Response of faba bean grown on sandy soil to organic and inorganic nitrogen fertilization, Egyptian Journal of Soil Science, 31, 1991, 343-355.

[15] J.P. Sharma and S.N. Saxena, Use of crop residues and organic manures for improving phosphorus availability of maize (Zea mays L.), Indian Journal of Agricultural Research, 24, 1990, 119-122.

[16] S.S. Zamil, Q. F. Quadir, M.A.H. Chowdhury and A. Al Wahid., Effects of different animal manures on yield, quality and nutrient uptake by mustard cv. Agrani, BRAC University Journal, 1(2), 2004, 59-66.

[17] G. Heluf, Soil and water Management Research Program Summary Report of 2000/2001 Research Activities, Alemaya Research 
Mineral Nutrition and Quality of Maiz (Zea Mays L.) as Affected by Household Waste Compost,

Center, Alemaya University, 2002.

[18] S. Mohanty, N.K. Paikaray; A.R. Rajan, Availability and uptake of phosphorus from organic manures in groundnut (Arachis hypogea L.) corn (Zea mays L.) sequence using radio tracer technique, Soil Biology and Biochemistry, 38, 2006, 81-90.

[19] S. M. Bakhtiar and K.Sakurai, Effects of organic manure and chemical fertilizer on soil fertility and productivity of plant and ratoon crops of sugarcane, Archives of Agronomy and Soil science, 51, 2005,325-334.

[20] F.O. Adekayode, The use of manure to increase the yield of and quality of amaranthus to feed rabbit in a humid tropical region, Journal of Animal and Veterinary Advances, 3, 2004, 758-762

[21] F. Oad, C.U.A. Buriro and S.K. Agha, Effect of organic and inorganic fertilizer application on maize fodder production, Asian Journal of Plant Science, 3, 2004, 375-377.

[22] T. Prabu, P.R. Narwadkar, A.K. Sanindranath and M. Rafi, Effect of integrated nutrient management on growth and yield of okra cv.Parbhani Kranti, Orissa Journal of Horticulture, 31, 2003,17-21.

[23] T. Khaliq, T. Mahmood, J. Kamal and A. Masood, Effectiveness of farmyard manure, poultry manure and nitrogen for corn (Zea mays L.) productivity, International Journal of Agriculture \& Biology, 2, 2000, 260-263.

[24] P. R. Day, Particle fractionation and particle size analysis, in C. A. Black (Ed.), Methods of Soil Analysis. Part I. Agronomy Monograph, (New York. Academic Press, 1965) 545-567.

[25] A. Walkley and I.A. Black, An examination of the Degtjareff method for determining organic carbon in soils: Effect of variations in digestion conditions and of inorganic soil constituents, Soil Science, 63, 1934, 251-263.

[26] R.H. Bray and L.T Kurtz, Determination of total, organic, and available forms of phosphorus in soils, Soil Science, 59, 1945, 3945.

[27] M L. Jackson, Soil Chemical Analysis (India, New Delhi, Prentice Hall of India Private Limited, 1973).

[28] S. E. Allen, H. M. Grimshaw and A.P. Rowland, Chemical Analysis, in P. D. Moore and S. B. Chapman (Eds.), Methods in Plant Ecology (Blackwell Scientific Publications, 1986) 285-344.

[29] M. Shahnawaz, S.A. Sheikh and S. M., Nizamani, Determination of Nutritive Values of Jamun Fruit (Eugenia jambolana) Products, Pakistan Journal of Nutrition. 8 (1), 2009, 275-1280.

[30] Excel Inc. Microsoft Excel for Windows (USA, Microsoft Corporation, 2003).

[31] SPSS Inc., Statistics (Chicago, SPSS Inc. 2003).

[32] D. Muhammad and R.A. Khattak, Growth and nutrient concentrations of maize in pressmud treated saline-sodic soils, Soil \& Environment, 28 (2), 2009, 145-155.

[33] T. Aziz, S. Ullah, A. Sattar, M. Nasim, M. Farooq, and M.M. Khan, Nutrient availability and maize (Zea mays L.) growth in soil amended with organic manures. International Journal of Agriculture \& Biology, 12, 2010, 621-624.

[34] T. Aziz, Rahmatullah, M.A. Maqsood, M.A.. Tahir, I. Ahmad and M.A. Cheema, Phosphorus utilization by six Brassica cultivars (Brassica juncea L.) from tri-calcium phosphate; a relatively insoluble P compound, Pakistan Journal of Botany, 38(5), 2006, $1529-1538$.

.[35] O. O. Ologunde, Effect of nitrogen and population on yield and yield components of maize (Zea mays L.), M.S. Thesis, Graduate School, University of Missouri,1974.

[36] W. F. Bennett, Nitrogen, phosphorus and potassium content of corn leaf and grain as related to nitrogen fertilization and yield, Soil Science Society of America proceeding, 17, 1953, 252-258.

[37] F. Viets, G. Nelson and C.E. Crawford, The relationships among corn yields, leaf composition and fertilizers, Soil Science Society of America proceeding, 18, 1954, 297-301.

[38] H. A. Bruns and M. W. Ebelhar, Nutrient Uptake of Maize Affected by Nitrogen and Potassium Fertility in a Humid Subtropical Environment, (Publications from USDA-ARS / UNL Faculty, Paper 523, 2006).

[39] L.T. Kurtz and G. E. Smith, Nitrogen fertility requirements, in W.H Pierre, S.A. Aldrich and W.P. Martin (eds.), Advances in Corn Production (Iowa, Ames, The Iowa State University Press,1966) 195-235.

[40] M.A. Arun Kumar, S. K. Galli and R.V. Patil, Effect of levels of NPK on quality of sweet corn grown on vertisols, Karnataka Journal of Agricultural Sciences, 20, 2007, 44-46.

[41] M. Takebe, K. A Okazaki, N. Oka, T. Karasawa and M. Komada, Nitrogen uptake rate with compost application and its effect on the sugar content of sweet corn (Zea mays L.), 19th World Congress of Soil Science, Soil Solutions for a Changing World, Brisbane, Australia, 2010.

[42] A. Almodares, M. Jafarinia and M.R. Hadi, The Effects of Nitrogen Fertilizer on Chemical Compositions in Corn and Sweet Sorghum, American-Eurasian Journal of Agriculture \& Environmental Science, 6 (4), 2009, 441-446.

[43] Naserirad, H., Soleymanifard, A., and Naseri, R., Effect of Integrated Application of Bio-fertilizer on Grain Yield, Yield Components and Associated Traits of Maize Cultivars, American-Eurasian Journal of Agriculture \& Environmental Science, 10 (2), 2011, 271-277.

[44] V. Raja, Effect of nitrogen and plant population on yield and quality of super sweet corn (Zea mays L.), Indian Journal of Agronomy, 46, 2001, 247-250.

[45] W. H. Thomas, D.L.R. Seibert, M. Alden, A. Neori, and P. Eldridge, Yields, photosynthetic efficiencies and proximate composition of dense marine micro algal cultures. I. Introduction and Phaeodactylum tricornutum experiments, Biomass, 5(3), 1984, 181-209.

[46] L. E.Gauer, C. A. Grant, D. T Gehl and L. D Bailey, Effects of nitrogen fertilization on grain protein content, nitrogen uptake, and nitrogen use efficiency of six spring wheat (Triticum aestivum L.) cultivars, in relation to estimated moisture supply, Canadian Journal of Plant Science, 72, 1992, 235-241. 